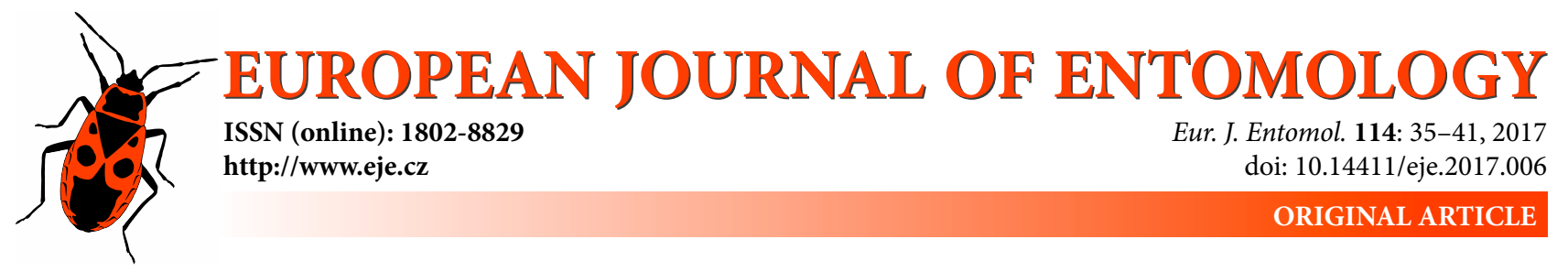

\title{
Effect of temperature on rate of development, survival and adult longevity of Phthorimaea operculella (Lepidoptera: Gelechiidae)
}

\author{
Stefanos S. ANDREADIS ${ }^{1, *}$, Christos G. SPANOUDIS ${ }^{1}$, Georgia ZAKKA ${ }^{1}$, Barbara ASLANIDOU $^{2}$, Sofia NOUKARI ${ }^{2}$ \\ and MATILDA SAVOPOULOU-SOULTANI ${ }^{1}$

\begin{abstract}
${ }^{1}$ Aristotle University of Thessaloniki, Faculty of Agriculture, Laboratory of Applied Zoology and Parasitology, 54124 Thessaloniki, Greece; e-mails: matilda@agro.auth.gr, chrisp83@agro.auth.gr, georgia.zakka@gmail.com
\end{abstract} \\ 2 Technological Educational Institution of Thessaloniki, Crop Production Department, Laboratory of Entomology, 57400 Sindos, \\ Thessaloniki, Greece; e-mails: barbarafpfp8989@hotmail.com, sofianouk89@hotmail.com
}

Key words. Lepidoptera, Gelechiidae, Phthorimaea operculella, potato tuberworm, constant temperatures, development, adult longevity, survival, developmental threshold

\begin{abstract}
The potato tuberworm, Phthorimaea operculella Zeller (Lepidoptera: Gelechiidae), is a major pest of potato, Solanum tuberosum L. (Solanales: Solanaceae), both in the field and storehouses. The rate of development and survival of $P$. operculella, reared on potato tubers cv. Spunta at eight constant temperatures $\left(17.5,20,22.5,25,27.5,30,32.5\right.$ and $\left.35^{\circ} \mathrm{C}\right)$, were studied in the laboratory. The duration of development of the immature stages was recorded. Adult longevity was also recorded under the same conditions. Developmental time decreased significantly with increase in temperature within the range $17.5-32.5^{\circ} \mathrm{C}$. No development occurred at $35^{\circ} \mathrm{C}$. Survival (\%) from egg to adult was higher at temperatures within the range $17.5-27.5^{\circ} \mathrm{C}$ than at either 30 or $32.5^{\circ} \mathrm{C}$. Linear and a non-linear (Logan I) models were fitted to our data in order to describe the developmental rate of the immature stages of $P$. operculella as a function of temperature and estimate the thermal constant $(K)$ and critical temperatures (i.e., lower developmental threshold, optimum temperature for development, upper developmental threshold). Lower developmental threshold and optimum temperature for development ranged between $12.5-16.2$ and $31.7-33.8^{\circ} \mathrm{C}$, respectively. The estimated upper developmental threshold for total immature development was $35.0^{\circ} \mathrm{C}$. Thermal constant for total development was 294.0 degree-days. Adult longevity was significantly shorter at high $\left(30\right.$ and $\left.32.5^{\circ} \mathrm{C}\right)$ than at low temperatures $\left(17.5-27.5^{\circ} \mathrm{C}\right)$. Our results not only provide a broader insight into the thermal biology of $P$. operculella, but also can be used as an important tool in planning an effective pest control program both in the field and storehouses.
\end{abstract}

\section{INTRODUCTION}

The potato tuberworm, Phthorimaea operculella (Zeller) (Lepidoptera: Gelechiidae), is the most important pest of potato (Solanum tuberosum L.) and other Solanaceae crops (Das \& Raman, 1994; Rondon, 2010; Kroshel \& Schaub, 2012, Navrozidis \& Andreadis, 2012). It originates from South America, however, at present it occurs in almost all tropical, subtropical and temperate regions where potatoes are grown (Cisneros \& Gregory, 1994; Rondon, 2010; Saour et al., 2012) as it has adapted to a wide range of climatic conditions (Kroschel \& Koch, 1994; Kroschel et al., 2013). It has a variable number of generations per year depending on geographical location and temperature (Choe et al., 1980; Capinera, 2008; Rondon, 2010). Under favourable conditions, such as in areas where winters are mild and potato is a year-round crop and there are piles of culled potatoes, potato tubers left in the soil after harvest and volunteer plants (Coll et al., 2000; Rondon et al., 2007; Capinera, 2008; Dögramaci et al., 2008; Rondon, 2010) it does not undergo diapause, but continues to develop in the short spells when temperature is above its lower developmental threshold (Kroschel et al., 2013). However, in subtropical regions of Southern Europe, the long, cold winters generally restrict its development and as a consequence it is not an important pest (Kroschel et al., 2013).

Temperature is one of the most important environmental factors for insects since it strongly affects their growth and many other life history traits (Steigenga \& Fischer, 2009). Thus, their thermal requirements and developmental rates at different temperatures are of critical importance for determining the environmental conditions that are necessary for them to become pests (Bahar et al., 2012). In addition, understanding the physiological relationship between temperature and development rate is important in the predic-

\footnotetext{
* Present and corresponding address: Pennsylvania State University, Department of Entomology, Chemical Ecology Lab, University Park, 16802 PA, USA; e-mail: ssa18@psu.edu
} 
tion of population outbreaks and timely management of pests on crops (Jervis \& Copland, 1996; van der Have, 2008).

Temperature-driven models based on functional relationships between insect development and ambient temperature are most often used to predict the activity and seasonal population dynamics of pests and natural enemies in the field (Frazer \& McGregor, 1992; Brière \& Pracros, 1998). The simplest model is a linear one which enables the prediction of the lower developmental threshold and thermal constant within limited ranges of temperatures (Campbell et al., 1974; Kontodimas et al., 2004; Shi et al., 2011; Brar et al., 2015). Nevertheless, for a more accurate description of the temperature dependence of mean developmental rates over a wide range of temperatures, there are several nonlinear models that enable us to estimate the optimum temperature for development and upper developmental threshold (Logan et al., 1974; Lactin et al., 1995; Brière et al., 1998; Kontodimas et al., 2004, Kontodimas, 2012).

Over the last three decades there have been numerous studies on the effect of temperature on $P$. operculella, which provide valuable information and insight into its population dynamics in a variety of ecosystems both in the field and storehouses (Al-Ali et al., 1975; Briese, 1980; Choe et al., 1980; Chauhan \& Verma, 1990; Kroschel \& Koch, 1994; Sporleder et al., 2004; Golizadeh \& Zalucki, 2012; Golizadeh et al., 2012). However, in most of these studies the critical temperatures were estimated using linear equations in which development and reproduction are practically confined to temperatures within the linear region of the development curve (Gilbert \& Raworth, 1996; Shi et al., 2011; Jafari et al., 2012). In addition, the results are for populations originating from geographical areas with certain climatic characteristics. Thus, additional quantitative sets of data are needed to develop more accurate models for predicting the population development of $P$. operculella, particularly in southern Europe.

The objective of this study was to determine the effect of temperature on development, survival to adulthood and adult longevity of $P$. operculella originating from a typical Mediterranean climate with mild and rainy winters, relatively warm and dry summers and, generally, extended periods of sunshine throughout most of the year. The relationship between temperature and rate of development was described using linear (common) and nonlinear models (Logan I). A better understanding of its thermal biology and more accurate estimates of its lower and upper developmental thresholds, thermal constant and optimum temperature for development (temperature at which the maximum rate of development occurs), may allow us to manipulate this pest in a more accurate way in order to enhance the efficacy of IPM in areas with a similar climate. Moreover, it may also, at a fine scale, provide an insight into host plant-insect synchrony and at a broad scale, the geographic distribution of this species.

\section{MATERIALS AND METHODS}

\section{Rearing}

Original population of $P$. operculella was collected from infested potato tubers of the widely used table variety Spunta at Kato Nevrokopi (northern Greece) $\left(41^{\circ} 20^{\prime} \mathrm{N}, 23^{\circ} 51^{\prime} \mathrm{E}\right)$ in September 2011. Immature stages of $P$. operculella were reared on tubers of the same variety in wooden cages $(30 \times 30 \times 30 \mathrm{~cm})$ at $25 \pm 1{ }^{\circ} \mathrm{C}$, $60 \pm 5 \% \mathrm{RH}$ and a $16 \mathrm{~L}: 8 \mathrm{D}$ photoperiod. Emerging adults were kept in the same cages and provided with a $20 \%$ sucrose solution.

\section{Egg laying}

Four to five pairs of newly emerged adults of both sexes were placed in truncated transparent plastic cups $(13 \times 6.5 \mathrm{~cm})$ covered with fine mesh. Three holes were punched at the bottom of each cup and were plugged with dental roll wick, which provided the adults with a $20 \%$ sucrose solution. Any eggs the adults laid on the fine mesh were collected daily with a fine brush and placed into small plastic boxes $(4.5 \times 3.0 \mathrm{~cm})$ prior use. After 3 days adults were transferred back to the wooden cages.

\section{Effect of temperature on survival}

Eggs of $P$. operculella of the same age were collected with a fine brush and placed in groups of ten on a potato tuber within a new transparent plastic cup of the same size. Afterwards they were transferred to incubators (Precision Scientific, General Electric, Louisville, KY) kept at eight constant temperatures (17.5, $20,22.5,25,27.5,30,32.5$ and $\left.35^{\circ} \mathrm{C}\right)$ under a $16 \mathrm{~L}: 8 \mathrm{D}$ photoperiod. Temperature in the incubators was monitored using internal thermometers. The variation in temperature in the incubators was $\pm 0.2^{\circ} \mathrm{C}$. The number of $P$. operculella individuals that successfully completed their development to adulthood at each temperature was recorded.

\section{Effect of temperature on developmental time}

Developmental time of $P$. operculella at seven constant temperatures was recorded in the same experiment. Daily observations were made to record the days needed for egg hatch, pupation and adult eclosion at each temperature.

\section{Lower developmental threshold}

The relationship between the rate of development and temperature was based on the linear regression equation of the form:

$y=a+b T$

where $y$ is the rate of development at temperature $T$, and $a$ and $b$ are constants that were estimated using the least squares method. The lower developmental threshold $(t)$ was calculated using $t=$ $-a / b$, while the thermal constant $(K)$ expressed in degree days $(D D)$ was estimated as $K=1 / b$ (Campbell et al., 1974). Standard errors (SE) for the lower developmental threshold and thermal constant were calculated using the equations of Campbell et al. (1974):

$S E_{t}=\frac{y_{m}}{b} \sqrt{\frac{s^{2}}{N \times y_{m}^{2}}+\left(\frac{S E_{b}}{b}\right)^{2}}$ and $S E_{k}=\frac{S E_{b}}{b^{2}}$

where $y_{m}$ is the sample mean, $b$ is the linear equation parameter, $s^{2}$ is the residual mean square, and $N$ is the sample size (number of constant temperatures used).

The linear regressions included all the data obtained from the experiments except $35^{\circ} \mathrm{C}$ since no development was recorded at that temperature. 

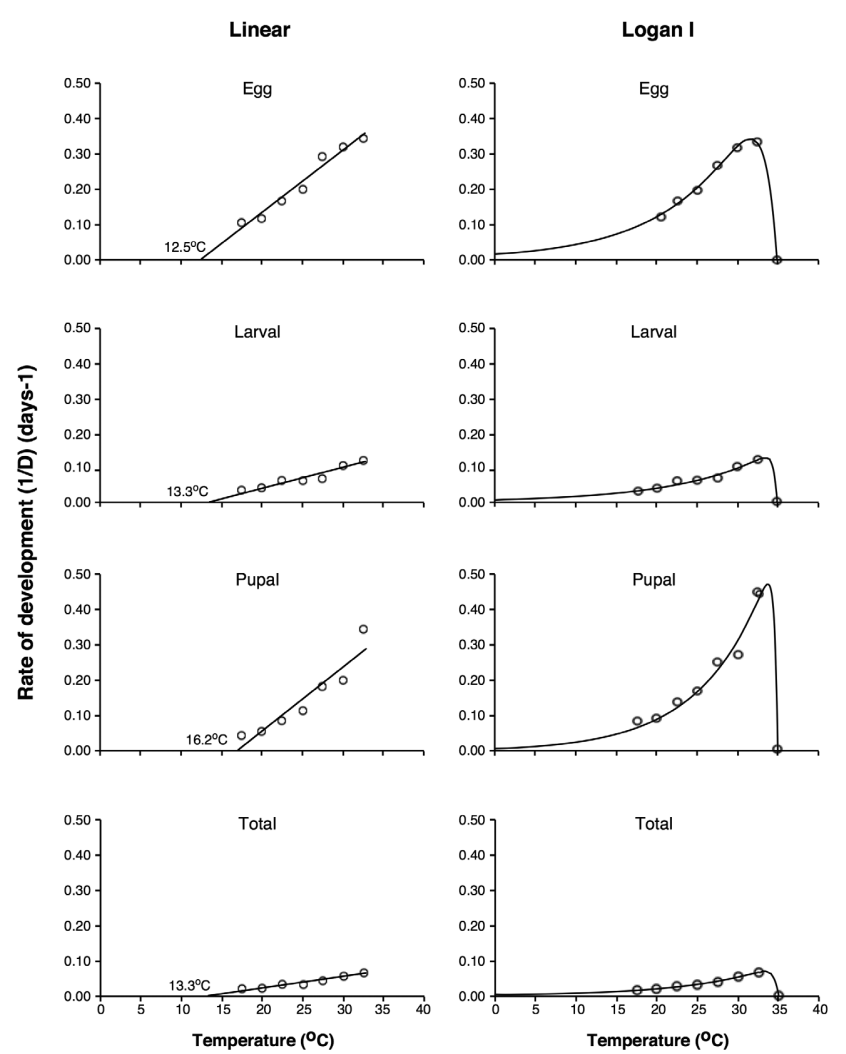

Fig. 1. Fitting the linear and Logan I models (solid lines) to observed values (white circles) of developmental rates of $P$. operculeIla (egg, larval, pupal and entire immature development) reared on potato tubers of cv. Spunda. In the linear model, the development time at $35^{\circ} \mathrm{C}$ was omitted.

\section{Upper developmental threshold}

The estimate of the upper developmental threshold was based on the Logan I nonlinear model (Logan et al., 1976). The equation for this model is:

$$
d(T)=\psi x\left[e^{\rho T}-e^{\rho T_{m}-\frac{T_{m}-T}{\Delta T}}\right]
$$

where $d(T)$ is the rate of development at temperature $T\left({ }^{\circ} \mathrm{C}\right), \psi$ is a directly measurable rate of temperature-dependent physiological process at some base temperature $T_{b}, \rho$ is a composite $\mathrm{Q}_{10}$ value for enzyme-catalyzed biochemical reactions, $T_{m}$ is the maximum temperature at which the insect cannot survive for prolonged periods of time, and $\Delta T$ is a temperature range, above the optimum temperature for development and below $T_{m}$. The base temperature $\left(T_{b}\right)$ is either the minimum temperature used in the experiments or it can be hypothesized that $T_{b}=0^{\circ} \mathrm{C}$. In the present study, the base temperature was considered to be $0^{\circ} \mathrm{C}$ for simplification of the model (Got et al., 1997).

Optimum temperature $\left(T_{o}\right)$ for development was calculated using the equation of Logan et al. (1976):

$$
T_{o}=T_{m} \times\left[1+\varepsilon \times \frac{\ln \left(\varepsilon \times b_{o}\right)}{1-\varepsilon \times b_{o}}\right]
$$

where $\varepsilon=\Delta T / T_{m}$ and $b_{o}=\rho \times T_{m}$

\section{Effect of temperature on adult longevity}

After adults of $P$. operculella emerged they were placed individually in plastic boxes $(4.8 \times 7.5 \times 11.5 \mathrm{~cm})$. Sucrose solution $(20 \%)$ was provided as food and renewed frequently to prevent
Table 1. Developmental time (days $\pm \mathrm{SE}$ ) of $P$. operculella reared

\begin{tabular}{|c|c|c|c|c|c|}
\hline \multirow{2}{*}{$\begin{array}{c}\text { Mean } \\
\text { temperature } \\
\left({ }^{\circ} \mathrm{C}\right) \\
\end{array}$} & \multirow[b]{2}{*}{$\mathrm{n}$} & \multicolumn{4}{|c|}{ Developmental time (days \pm SE) } \\
\hline & & Egg to larva & $\begin{array}{c}\text { Larva to } \\
\text { pupa }\end{array}$ & $\begin{array}{c}\text { Pupa to } \\
\text { adult }\end{array}$ & Total \\
\hline 17.5 & 140 & $\begin{array}{c}10.1 \pm 0.1 a \\
(9-17)\end{array}$ & $\begin{array}{c}33.1 \pm 0.3 a \\
(26-50)\end{array}$ & $\begin{array}{c}16.7 \pm 0.3 a \\
(14-22)\end{array}$ & $\begin{array}{r}60.1 \\
(54\end{array}$ \\
\hline 20 & 134 & $\begin{array}{c}8.4 \pm 0.1 b \\
(8-9)\end{array}$ & $\begin{array}{c}28.1 \pm 0.4 b \\
(24-37)\end{array}$ & $\begin{array}{c}14.4 \pm 0.4 b \\
(9-18)\end{array}$ & $\begin{array}{r}54.4 \\
(47\end{array}$ \\
\hline 22.5 & 140 & $\begin{array}{c}6.1 \pm 0.1 c \\
(6-8)\end{array}$ & $\begin{array}{c}17.6 \pm 0.3 c \\
(16-21)\end{array}$ & $\begin{array}{r}9.5 \pm \\
(6-\end{array}$ & $\begin{array}{r}33.2 \\
(30\end{array}$ \\
\hline 25 & 140 & $\begin{array}{c}5.3 \pm 0.1 d \\
(3-10)\end{array}$ & $\begin{array}{c}17.1 \pm 0.3 c \\
(13-24)\end{array}$ & $\begin{array}{c}7.8 \pm 0.2 d \\
(4-10)\end{array}$ & $\begin{array}{c}30.9 \pm 0.4 c \\
(27-38)\end{array}$ \\
\hline 27.5 & 140 & $\begin{array}{c}3.8 \pm 0.1 \mathrm{e} \\
(2-4)\end{array}$ & $\begin{array}{c}15.5 \pm 0.3 d \\
(14-17)\end{array}$ & $\begin{array}{c}5.2 \pm 0.1 \mathrm{e} \\
(3-7)\end{array}$ & $\begin{array}{c}24.6 \pm 0.2 e \\
\quad(21-28)\end{array}$ \\
\hline 30 & 140 & $\begin{array}{c}3.2 \pm 0.1 f \\
(3-4)\end{array}$ & $\begin{array}{c}10.5 \pm 0.4 \mathrm{e} \\
(8-16)\end{array}$ & $\begin{array}{c}4.8 \pm 0.2 \mathrm{ef} \\
(3-6)\end{array}$ & $\begin{array}{c}18.4 \pm 0.4 f \\
(15-21)\end{array}$ \\
\hline 32.5 & 135 & $\begin{array}{c}3.0 \pm 0.1 f \\
(3-4)\end{array}$ & $\begin{array}{c}8.6 \pm 0.5 f \\
(8-10)\end{array}$ & $\begin{array}{c}2.9 \pm 0.1 f \\
(2-3)\end{array}$ & $\begin{array}{c}14.3 \pm 0.3 f \\
(14-15)\end{array}$ \\
\hline
\end{tabular}
at seven different constant temperatures.

$\mathrm{n}$ - number of individuals; ( $)-$ minimum and maximum value of developmental time; values in a column followed by the same lower case letter are not significantly different (One way ANOVA followed by Tukey's HSD test, $p<0.05$ ); all individuals failed to complete development at $35^{\circ} \mathrm{C}$.

mould. Adult longevity was recorded daily at each temperature until it died.

\section{Statistical analysis}

One way analysis of variance (ANOVA) was carried out to test the effect of temperature on developmental time and adult longevity of $P$. operculella. Means were compared using the Tukey's HSD test to identify all pairwise comparisons that were statistically significantly different after controlling for the experiment wise error rate. Calculations of the linear model were performed using Microsoft Excel for Mac 2011 (version 14.3.9). The nonlinear regression was carried out using the statistical program JMP (SAS Institute, 2007). Survival of $P$. operculella at each constant temperature was examined in one analysis by a generalized linear model (GLM) with a binomial error distribution and logit-link function. The significance of the explanatory variable (temperature) of the model was tested using a likelihood ratio test. Results are presented as means \pm confidence intervals (C.I.). All statistical tests incorporate a Type I error rate of $\alpha=0.05$, and all parametric statistics apart from the nonlinear regression were carried out using the R software version 2.15 .2 (2012). Figures were created in Adobe Illustrator CS5 (version 15.0.2).

\section{RESULTS}

\section{Effect of temperature on survival}

Phthorimaea operculella developed successfully from egg to adult emergence at all the temperatures except $35^{\circ} \mathrm{C}$ at which they all failed to complete their development. The highest percentage survivals were recorded at 25 (78.6\%) and $27.5^{\circ} \mathrm{C}(74.3 \%)$, which are significantly greater than those recorded at $17.5(45.0 \%), 20(44.8 \%), 22.5(61.4 \%)$, $30(27.1 \%)$ and $32.5^{\circ} \mathrm{C}(11.8 \%)$ (GLM with likelihood ratio test, $P<0.001$ ) (Fig. 1).

\section{Effect of temperature on developmental time}

The results of the effect of temperature on the development of $P$. operculella are presented in Table 1. Developmental time decreased significantly linearly with increase 


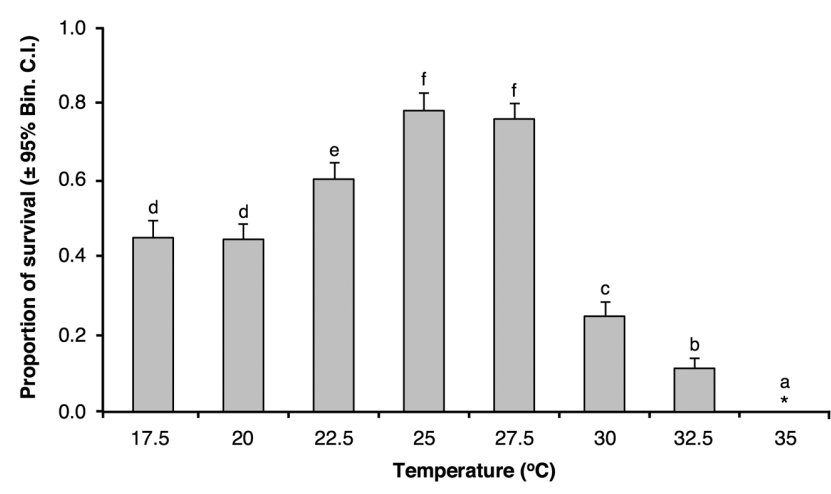

Fig. 2. Proportion ( $\pm 95 \%$ binomial C.I.) of $P$. operculella that survived at the different constant temperatures used. Bars with different lettering denote significant differences among means (GLM with binomial error distribution followed by Tukey's HSD, $P<$ 0.001).

in temperature within the range 17.5 to $32.5^{\circ} \mathrm{C}$ (Fig. 2), which is also indicated by the high values of coefficients of determination $\left(R^{2}=0.879-0.965\right)$ (Table 2). Duration of all developmental stages (egg, larval, pupal, total) of $P$. operculella differed significantly among various temperatures (egg: $F_{6,622}=1129.0, P<0.001$; larval: $F_{6,363}=627.6$, $P<0.001$; pupal: $F_{6,257}=320.1, P<0.001$; total: $F_{6,257}=$ 1219.0, $P<0.001)$. The shortest developmental time was recorded at $32.5^{\circ} \mathrm{C}(14.3$ days $)$ and the longest at $17.5^{\circ} \mathrm{C}$ (60.1 days) (Table 1$)$.

\section{Lower developmental threshold}

The lower threshold and the number of degree-days (DD) required for the development of each life stage were estimated using the linear regression model. The lowest developmental thresholds $(t)$ of the various developmental life stages ranged from 12.5 to $16.2^{\circ} \mathrm{C}$ at the different constant temperatures used (Table 2). Likewise, DD requirements varied with life stage as the thermal constant $(K)$ for egg, larval, pupal and total development was estimated to be 57.6, 177.1, 52.3 and 294.0 DDs, respectively (Table 2).

\section{Upper developmental threshold}

The upper developmental threshold $\left(T_{m}\right)$ recorded for egg, larval, pupal and total development (egg to adult) was $35.0^{\circ} \mathrm{C}$ (Table 3). Optimum developmental temperature $\left(T_{o}\right)$ of egg, larval, pupal and total development (egg to adult) varied very little varying between 31.7 and $33.8^{\circ} \mathrm{C}$ at the temperatures tested (Table 3).

\section{Effect of temperature on adult longevity}

Adult longevity of $P$. operculella decreased with increase in temperature within the range $17.5-30^{\circ} \mathrm{C}$ (Table 4). Lon-
Table 2. Linear regression of developmental rate of different developmental stages of $P$. operculella recorded over a range of constant temperatures.

\begin{tabular}{ccccc}
\hline $\begin{array}{c}\text { Develop- } \\
\text { mental stage }\end{array}$ & Regression equation & $R^{2}$ & $t \pm \mathrm{SE}$ & $K \pm \mathrm{SE}$ \\
\hline Egg & $\mathrm{y}=-0.2175+0.0174 \times$ & 0.965 & $12.5 \pm 1.1$ & $57.6 \pm 4.9$ \\
Larva & $\mathrm{y}=-0.0747+0.0056 \times$ & 0.922 & $13.2 \pm 1.7$ & $177.1 \pm 23.0$ \\
Pupa & $\mathrm{y}=-0.3103+0.0191 \times$ & 0.879 & $16.2 \pm 1.7$ & $52.3 \pm 8.7$ \\
Total & $\mathrm{y}=-0.0470+0.0034 \times$ & 0.950 & $13.8 \pm 1.3$ & $294.0 \pm 30.1$ \\
\hline
\end{tabular}

$R^{2}$ - coefficient of determination (linear); $\mathrm{t}$ - lower temperature thresholds $\left({ }^{\circ} \mathrm{C}\right)$; $\mathrm{K}$ : thermal constant (DD); data used was recorded at seven constant temperatures $(17.5,20,22.5,25,27.5,30$ and $\left.32.5^{\circ} \mathrm{C}\right)$.

gevity was significantly shorter at $30^{\circ} \mathrm{C}(9.4$ days $)$ and $32.5^{\circ} \mathrm{C}$ (11.1 days) than at 27.5 (22.9 days), 25 (24.1 days), 22.5 (31.4 days), 20 (36.1 days) and $17.5^{\circ} \mathrm{C}$ (52.3 days) $\left(F_{6,242}=25.4, P<0.001\right)$ (Table 4$)$.

\section{DISCUSSION}

Temperature-dependent development in insects has been frequently investigated during the last few decades. Temperature is considered to affect several biological characteristics of insects, such as, developmental time and fecundity, and as a consequence their activity and population dynamics in the field is dictated by ambient temperature. Therefore, there has been considerable interest for a long time in the temperature relationships of developmental time and fecundity of serious pests, in order to predict outbreaks and their population dynamics (Ratte, 1985).

Our results provide evidence that temperature has indeed a great effect on percentage survival, developmental time of immature stages and adult longevity of $P$. operculella. Indeed, $P$. operculella completed its lifespan at all the constant temperatures used except $35^{\circ} \mathrm{C}$. The percentage survival was high at most of the temperatures used, except 30 and $32.5^{\circ} \mathrm{C}$, at which the survival of the immature stages was very low. The highest values of survival were recorded at 25 and $27.5^{\circ} \mathrm{C}$, which were significantly higher than those recorded at $17.5,20,22.5,30$ and $32.5^{\circ} \mathrm{C}$. This is in agreement with a previous study in which survival from egg hatch to adult emergence depended on temperature (Briese, 1980). Maximum survival of $85-94 \%$ was recorded at $26^{\circ} \mathrm{C}$ followed by a steep decline at lower temperatures due to an additional mortality factor: the apparent inability of some larvae to penetrate into potato tubers and become established (Briese, 1980). According to Golizadeh et al. (2012) the percentage survival of the immature stages initially increases with increase in temperature from 16 to $28^{\circ} \mathrm{C}$ and thereafter decreases with further increase

Table 3. Parameter estimates of Logan I model for development of $P$. operculella recorded at eight constant temperatures.

\begin{tabular}{ccccccc}
\hline Developmental stage & $\psi \pm \mathrm{SE}$ & $\rho \pm \mathrm{SE}$ & $T_{m} \pm \mathrm{SE}$ & $\Delta T \pm \mathrm{SE}$ & $T_{o}$ & $r^{2}$ \\
\hline Egg & $0.0157 \pm 0.0031$ & $0.1026 \pm 0.0077$ & $35.0001 \pm 0.0247$ & $1.5142 \pm 0.1806$ & 31.7 & 0.9978 \\
Larva & $0.0065 \pm 0.0019$ & $0.0889 \pm 0.0105$ & $35.0051 \pm 0.0000$ & $0.4487 \pm 1.2330$ & 33.5 & 0.9785 \\
Pupa & $0.0063 \pm 0.0022$ & $0.1223 \pm 0.0119$ & $35.0075 \pm 0.0000$ & $0.3855 \pm 0.8384$ & 33.8 & 0.9782 \\
Total & $0.0028 \pm 0.0006$ & $0.0995 \pm 0.0083$ & $35.0186 \pm 0.0000$ & $0.6170 \pm 0.3979$ & 33.2 & 0.9872 \\
\hline
\end{tabular}

$\psi, \rho, \Delta T$ - Logan equation parameters; $T_{m}$ - maximum temperature threshold $\left({ }^{\circ} \mathrm{C}\right) ; \mathrm{T}_{0}$ - optimum temperature for development $\left({ }^{\circ} \mathrm{C}\right) ; \mathrm{r}^{2}-$ non-linear regression coefficient; data were recorded at eight constant temperatures $\left(17.5,20,22.5,25,27.5,30,32.5\right.$ and $\left.35^{\circ} \mathrm{C}\right)$. 
Table 4. Adult longevity (days $\pm \mathrm{SE}$ ) of $P$. operculella recorded at seven constant temperatures.

\begin{tabular}{cccc}
\hline Mean temperature $\left({ }^{\circ} \mathrm{C}\right)$ & $\mathrm{n}$ & Adult longevity (days \pm SE) & Range \\
\hline 17.5 & 63 & $52.3 \pm 3.6 \mathrm{a}$ & $5-106$ \\
20 & 23 & $36.1 \pm 3.1 \mathrm{~b}$ & $15-63$ \\
22.5 & 42 & $31.4 \pm 2.2 \mathrm{bc}$ & $6-57$ \\
25 & 51 & $24.1 \pm 1.5 \mathrm{c}$ & $6-51$ \\
27.5 & 48 & $22.9 \pm 1.4 \mathrm{c}$ & $7-45$ \\
30 & 19 & $9.4 \pm 1.1 \mathrm{~d}$ & $3-21$ \\
32.5 & 8 & $11.1 \pm 1.3 \mathrm{~d}$ & $2-14$ \\
\hline
\end{tabular}

$\mathrm{n}$ - number of individuals; Range - range of values; values in a column followed by the same lower case letter are not significantly different (One way ANOVA followed by Tukey's HSD test, $p<0.05$ ).

in temperature. In the same study, percentage survival was lower at the upper and lower temperature thresholds for development (near 16 and $32^{\circ} \mathrm{C}$ ) while percentage survival for the entire immature development was higher at 24 and $28^{\circ} \mathrm{C}$ than at the other temperatures used. Furthermore, no immatures survived at $36^{\circ} \mathrm{C}$, which is the same as recorded in this study.

Concerning developmental time, Choe et al. (1980) report that the development of $P$. operculella from egg to adult is completed in an average of 49.4, 39, 26.1 and 21 days at $18.2,19.6,24.2$ and $26.8^{\circ} \mathrm{C}$, respectively. Likewise, total developmental time from egg to adult is significantly affected by temperature and ranged from 17 days at $32^{\circ} \mathrm{C}$ to 75.5 days at $16^{\circ} \mathrm{C}$ (Golizadeh \& Zalucki, 2012; Golizadeh et al., 2012). An identical trend was recorded in our study, as developmental time was negatively correlated with temperature. More specifically total developmental time of $P$. operculella decreased significantly with increasing temperature in a linear fashion within the range 17.5 to $32.5^{\circ} \mathrm{C}$.

Linear correlation of development rate of $P$. operculella egg, larval and pupal stages with temperature between 17.5 and $32.5^{\circ} \mathrm{C}$ resulted in an estimated lower developmental threshold of $12.5,13.2$ and $16.2^{\circ} \mathrm{C}$, respectively. In another study, the estimated theoretical lower developmental thresholds of egg, larval, and pupal stages of $P$. operculella are notably lower, at $11.4,11.3$, and $12.2^{\circ} \mathrm{C}$, respectively (Golizadeh \& Zalucki, 2012). Briese (1980) reports that a regression of development rate on temperature gave values for the lower threshold of development of $12^{\circ} \mathrm{C}$ for females and $12.4^{\circ} \mathrm{C}$ for males, which is slightly lower than the value we obtained for total development. Other studies report a lower developmental threshold of $13.3^{\circ} \mathrm{C}$ for a Peruvian population (Sporleder et al., 2004), $11.1^{\circ} \mathrm{C}$ for a field population in North America (Langford \& Cory, 1932) and $9.5^{\circ} \mathrm{C}$ for South African laboratory moths (Broodryk, 1971), which indicates that there is considerable variability between populations, possibly reflecting local adaptation (Briese, 1980).

Likewise, in the current study, DD requirements varied with life stage as the thermal constant $(K)$ for egg, larval and pupal stages, and for total development was estimated at 57.6, 177.1, 52.3 and 294.0 DDs, respectively. These values differ from those previously reported of $65.3,165.1$ and 107.6 degree-days (DD) for the egg, larval, and pupal stages, respectively (Sporleder et al., 2004). As mentioned above, differences in rearing procedures, origin of insects, potato cultivars and selected temperature ranges might account for the different values (Sporleder et al., 2004; Golizadeh et al., 2014, Eliopoulos \& Kontodimas, 2016).

The upper developmental thresholds for the egg, larval and pupal stages were estimated to be $35.0^{\circ} \mathrm{C}$, which is slightly lower than that reported in a previous study (Golizadeh \& Zalucki, 2012), however, this value is in accord with our record of no successful development at $35.0^{\circ} \mathrm{C}$. The optimum developmental temperatures of egg, larva, pupa and total development varied between 31.7 and $33.8^{\circ} \mathrm{C}$ for the temperatures used. These values are slightly higher than those recorded for a population from a different geographical region (western Iran) reared on potato tubers of a different cultivar (Agria) (Golizadeh \& Zalucki, 2012).

As regards the adult longevity of $P$. operculella, it decreased with increase in temperature within the range $17.5-30^{\circ} \mathrm{C}$. Longevity was significantly lower at 30 and $32.5^{\circ} \mathrm{C}$ than at the lower temperatures. This might be due to the fact that metabolic rate in insects is temperature dependent and as a result, adults at low temperatures survive for longer than those kept at high temperatures (Davidowitz $\&$ Nijhout, 2004). The same trend is reported by Sporleder et al. (2004) for both male and female moths of P. operculella. The differences in the longevity of adult males and females were not notable. Golizadeh's et al. (2012) also show that temperature significantly affects the longevity of the female moths. Adult female longevity tends to decrease with temperature, and the females kept at $16^{\circ} \mathrm{C}$ lived significantly longer than those kept at other temperatures. In contrast, adult life span is relatively low at all the temperatures used by Choe et al. (1980), with the highest value recorded at $15.1^{\circ} \mathrm{C}$ (17.6 days).

In conclusion, our findings show that temperature is a key factor in the development, survival and adult longevity of $P$. operculella. Fundamental to modelling a species phenology is an understanding of the rate of insect development in relation to temperature as it is important for pest management, specifically in predict the timing of development, reproduction and dormancy or migration (Roy et al., 2002). This effect of temperature can be described by specific rate functions of temperature for survival, reproduction, population growth and development (Jervis \& Copland, 1996). However, the development and percentage survival of $P$. operculella are known to be influenced by factors such as host plant and strain of $P$. operculella, thus further studies should be carried out on different populations using different cultivars of potato in order to obtain the best development models. In addition, it might be necessary to validate the model's predictions under fluctuating temperatures conditions, as they are generally considered to be more favourable for the development of insects than constant temperatures (Fischer et al., 2011).

\section{REFERENCES}

Al-Ali A.S., AL-Neamy I.K., Abbas S.A. \& Abdul-Masin A.M.E. 1975: Observations on the biology of potato tuber moth $P h$ - 
thorimaea operculella Zell. (Lepidoptera: Gelechiidae) in Iraq. - J. Appl. Entomol. 79: 345-351.

Bahar M.H., SoroKa J.J. \& Dosdall L.M. 2012: Constant versus fluctuating temperatures in the interactions between Plutella xylostella (Lepidoptera: Plutellidae) and its larval parasitoid Diadegma insulare (Hymenoptera: Ichneumonidae). — Environ. Entomol. 41: 1653-1661.

Brar G.S., Capinera J.L., Kendra P.E., Smith J.A. \& Peña J.A. 2015: Temperature-dependent development of Xyleborus glabratus (Coleoptera: Curculionidae: Scolytinae). — Fla Entomol. 98: 856-864.

Brière J.F. \& PraCros P. 1998: Comparison of temperaturedependent growth models with the development of Lobesia botrana (Lepidoptera: Tortricidae). - Environ. Entomol. 27: 94-101.

Brière J.F., Pracros P. \& Le Roux A.Y. 1998: Comparison of temperature-dependent growth models with the development of Lobesia botrana (Lepidoptera: Tortricidae). - Environ. Entomol. 28: 22-29.

BRIESE D.T. 1980: Characterization of a laboratory strain of the potato tuber moth, Phthorimaea operculella (Zeller) (Lepidoptera: Gelechiidae). - Bull. Entomol. Res. 70: 203-212.

BROODRYK S.W. 1971: Ecological investigations on the potato tuber moth, Phthorimaea operculella (Zeller) (Lepidoptera; Gelechiidae). - Phytophylactica 3: 73-84.

Campbell A., Frazer B.D., Gilbert N., Gutierrez A.P. \& MaCKAUER M. 1974: Temperature requirements of some aphids and their parasites. - J. Appl. Ecol. 11: 431-438.

CAPINERA J.L. 2008: Potato tuberworm, Phthorimaea operculella (Zeller) (Lepidoptera: Gelechiidae). In Capinera J.L. (ed.): Encyclopedia of Entomology. Vol. 3. 2nd ed. Springer, Dordrecht, pp. 3027-3030.

Chauhan U. \& Verma L.R. 1990: Biology of potato tuberworm, Phthorimaea operculella Zeller with special reference to pupal eye pigmentation and adult sexual dimorphism. - Entomophaga 16: 63-67.

Choe K., Yoo C. \& Chang Y. 1980: Studies in the life history of potato tuber moth, Phthorimaea operculella (Zeller) (Lepidoptera; Gelechiidae). - Korean J. Plant Prot. 19: 97-101.

Cisneros F. \& Gregory P. 1994: Potato pest management. - Asp. Appl. Biol. 39: 113-124.

Coll M., Gavish S. \& Dori I. 2000: Population biology of the potato tubermoth, Phthorimaea opercuella (Lepidoptera: Gelechiidae) in two potato cropping systems in Israel. - Bull. Entomol. Res. 90: 309-315.

Dangles O., Carpio C., Barragan A.R., Zeddam J.-L. \& Silvain J.-F. 2008: Temperature as a key driver of ecological sorting among invasive pest species in the tropical Andes. - Ecol. Appl. 18: 1795-1809.

Das G.P. \& Raman K.V. 1994: Alternate hosts of the potato tuber moth, Phthorimaea operculella (Zeller). - Crop Prot. 13 83-86.

Davidowitz G. \& Nishout H.F. 2004: The physiological basis of reaction norms: the interaction among growth rate, the duration of growth and body size. - Integr. Comp. Biol. 44: 443-449.

Dŏgramaci M., Rondon S.I. \& DeBano S.J. 2008: The effect of soil depth and exposure to winter conditions on survival of the potato tuberworm Phthorimaea operculella (Lepidoptera: Gelechiidae). - Entomol. Exp. Appl. 129: 332-339.

Eliopoulos P.A. \& Kontodimas D.C. 2015: Thermal development of Cephalonomia tarsalis (Hymenoptera: Bethylidae) parasitoid of the saw-toothed stored product beetles of the genus Oryzaephilus sp. (Coleoptera: Sylvanidae) - J. Therm. Biol. 56: 84-90.
Fischer K., Kolzow N., HoltJe H. \& Karl I. 2011: Assay conditions in laboratory experiments: is the use of constant rather than fluctuating temperatures justified when investigating temperature-induced plasticity? - Oecologia 166: 23-33.

FrAzer B.D. \& McGregor R.R. 1992: Temperature-dependent survival and hatching rate of eggs of seven species of Coccinellidae. - Can. Entomol. 124: 305-312.

Gilbert N. \& RAworth D.A. 1996: Insects and temperature, a general theory. - Can. Entomol. 128: 1-13.

GolizAdeH A. \& ZALUCKI M.P. 2012: Estimating temperaturedependent developmental rates of potato tuberworm, Phthorimaea operculella (Leidoptera: Gelechiidae). — Insect Sci. 19: 609-620.

Golizadeh A., Razmjou J., Rafiee-Dastjerdi H. \& Hassanpour M. 2012: Effects of temperature on development, survival and fecundity of potato tuberworm, Phthorimaea operculella (Lepidoptera: Gelechiidae) on potato tubers. - Am. J. Potato Res. 89: 150-158.

Golizadeh A., Esmaeili N., Razmjou J. \& Rafiee-Dastjerdi H. 2014: Comparative life tables of the potato tuberworm, $P h$ thorimaea operculella, on leaves and tubers of different potato cultivars. - J. Insect Sci. 14: 42, 11 pp.

Got B., Piry S., Migeon A. \& Labatte J.M. 1997: Comparison of different models for predicting development time of the European corn borer (Lepidoptera: Pyralidae). — Environ. Entomol. 26: 46-60.

Hemmati C., Moharramipour S. \& Talebi A.A. 2014: Effects of cold acclimation, cooling rate and heat stress on cold tolerance of the potato tuber moth Phthorimaea operculella (Lepidoptera: Gelechidae). — Eur. J. Entomol. 111: 487-494.

Jafari S., Fatthipour Y. \& FaraJI F. 2012: Temperature-dependent development of Neoseiulus barkeri (Acari: Phytoseiidae) on Tetranychus urticae (Acari: Tetranychidae) at seven constant temperatures. - Insect Sci. 19: 220-228.

Jervis M.A. \& Copland M.J.W. 1996: The life cycle. In Jervis M.A. \& Kidd N. (eds): Insect as Natural Enemies, a Practical Approaches to their Study and Evaluation. Chapman and Hall, London, pp. 63-161.

KontodimAs D.C. 2012: Nonlinear models for describing development and fecundity of the pseudococcid predators Nephus includens and Nephus bisignatus. - Entomol. Hell. 21: 13-24.

Kontodimas D.C., Eliopoulos P.A., Stathas G.J. \& Economou L.P. 2004: Comparative temperature-dependent development of Nephus includens (Kirsch) and Nephus bisignatus (Boheman) (Coleoptera: Coccinellidae), preying on Planococcus citri (Risso) (Homoptera: Pseudococcidae): evaluation of a linear and various non-linear models using specific criteria. Environ. Entomol. 33: 1-11.

Kroschel J. \& Koch W. 1994: Studies on the population dynamics of the potato tuber moth Phthorimaea operculella Zell. (Lep., Gelechiidae) in the Republic of Yemen. - J. Appl. Entomol. 118: 327-341.

Kroschel J. \& Schaub B. 2012: Biology and ecology of potato tuber moths as major pests of potato. In Giordanengo P., Vincent C. \& Alyokhin A. (eds): Insect Pests of Potato: Biology and Management. Elsevier, Oxford, pp. 165-192.

Kroschel J., Sporleder M., Tonnang H.E.Z., Juarez H., Carhuapom P., Gonzales J.C. \& Simon R. 2013: Predicting climatechange-caused changes in global temperature on potato tuber moth Phthorimaea operculella (Zeller) distribution and abundance using phenology modelling and GIS mapping. - Agric. For. Meteorol. 170: 228-241.

Lactin D.J., Holliday N.J., Johnson D.L. \& Craigen R. 1995: Improved rate of temperature-dependent development by arthropods. - Environ. Entomol. 24: 68-75. 
LANGFORD G.S. \& CORY E.N. 1932: Observations on the potato tuber moth. - J. Econ. Entomol. 25: 625-634.

Logan J.A., Hoyt D.J. \& TANIGOSHI L.K. 1976: An analytic model for description of temperature dependent rate phenomena in arthropods. - Environ. Entomol. 5: 1133-1140.

NAVROZIDIs E.I. \& ANDREADIS S.S. 2012: Applied Agricultural Entomology. CopyCity Publish, Thessaloniki, $538 \mathrm{pp}$.

R Core TeAm 2012: $R$ : A Language and Environment for Statistical Computing. R Foundation for Statistical Computing, Vienna. URL http://www.R-project.org/.

Ratte H.T. 1985: Temperature and insect development. In Hoffmann K.H. (ed.): Environmental Physiology and Biochemistry of Insects. Springer, Berlin, pp. 33-66.

Rondon S.I. 2010: The potato tuberworm: A literature review of its biology, ecology, and control. - Am. J. Potato Res. 87: 149-166.

Roy M., Brodeur J. \& Cloutier C. 2002: Relationship between temperature and development rate of Stethorus punctillum (Coleoptera: Coccinellidae) and its prey Tetranychus mcdanieli (Acarina: Tetranychidae). - Environ. Entomol. 31: 177-187.
Saour G., Al-Daoude A. \& Ismail H. 2012: Evaluation of potato tuber moth mortality following postharvest cold storage of potatoes. - Crop Prot. 38: 44-48.

SAS Institute Inc. 2007: JMP User's Guide. SAS Institute Inc., Cary, NC.

Shi P., Ge F., Sun Y. \& Chen C. 2011: A simple model for describing the effect of temperature on insect developmental rate. - J. Asia Pac. Entomol. 14: 15-20.

Sporleder M., Kroschel J., Gutierrez Quispe M.R. \& Lagnaoui A. 2004: A temperature-based simulation model for the potato tuberworm, Phthorimaea operculella Zeller (Lepidoptera; Gelechiidae). - Environ. Entomol. 33: 477-486.

Steigenga M.J. \& Fischer K. 2009: Fitness consequences of variation in developmental temperature in a butterfly. $-J$. Therm. Biol. 34: 244-249.

VAN DER Have T.M. 2008: Slaves to the Eyring Equation? Temperature Dependence of Life-history Characters in Developing Ectotherms. Ph.D. Thesis, Wageningen University, 168 pp.

Received May 13, 2016; revised and accepted November 22, 2016 Published online January 19, 2017 